\title{
A Study on the Acceptance Level of Rack Housing in Malaysia
}

\author{
C.M. Ho ${ }^{1}$, Q.N. Tan ${ }^{1}$, S.I. Doh ${ }^{1 *}$, J. Omar² and K. A Mohammed Al-Btoush ${ }^{3}$ \\ ${ }^{1}$ College of Engineering, Department of Civil Engineering, Universiti Malaysia Pahang, 26300 Pahang, Malaysia \\ 2Faculty of Civil Engineering Technology, Universiti Malaysia Pahang, 26300 Gambang, Pahang, Malaysia \\ ${ }^{3}$ Amman PO Box 33 and 22 Isra University Office 11622 Amman, Jordan
}

ABSTRACT - Rack housing is one type of modular construction system which is flexible and poses a higher degree of mobility. However, the idea of rack housing is relatively new and there is no clear indication of how far is the acceptance of Malaysian citizen to this idea. Therefore, this study aims to identify the acceptance level of Malaysian towards rack housing and also serve as the basic reference for both government and private sector for the adoption fo rack house in Malaysia. In this study, the acceptance level among Malaysian factors of consumer decision to purchase rack housing and also the perspective of Malaysian especially middle income group is determined. A set of questionnaire was made by Google form which contain question about the major factor of acceptance of Malaysian citizen on rack housing with total of 208 questionnaires. The data collected from different group of Malaysian was analyzed by using Average Index (Al). The degree of importance was determined by the rating scales. The result obtained is that the acceptance level to purchase rack housing based on location, comfortability and management factors. From the result, the respondances agree to accept rack housing to implement and construct in Malaysia.

ARTICLE HISTORY

Received: $15^{\text {th }}$ June 2021

Revised: 30th June 2021

Accepted: $16^{\text {th }}$ July 2021

\section{KEYWORDS}

Acceptance level

Modular construction

Rack housing

\section{INTRODUCTION}

Houseownship program is not longer a new campaign to encourage all household in Malaysia own a house. Various programs namely Five Year Plan (2016-2020) has been intiated by the government to develop affordbale home for both city and rural areas [1]. Besides that, the private sectors has also launched PR1MA and PPA1M1 to further support the government initiatives. Despite of numerous initiatives has been taken by both the government agencies and the private sectors, the middle-class in Malaysia particularly still unable to own a house due to the hike of debt among young Malaysians. The situation is became more critical with the high price increase of construction materials and the scarcity of suitable land for construction [2,3]. With the shift of lifestyle among young Malaysians, the current housing designed are perceived to be inflexible and poor in both design and quality.

Rack housing consider one type of modular construction system which consider as volumetric offsite fabrications that form an enclosed usable space which are structurally independent and include more than one building trade. Modular construction can be utilized for residential, commercial, or industrial applications [4]. However, in Malaysia, the idea of rack housing is rather new to the society. Since rack housing is still new to Malaysia, there is no clear cut sign of the acceptance level of the public towards living inside a rack housing [5]. This study will be a major strive in promoting the development of rack housing in Malaysia afterward. This research contributes to the social by inventing the degree of acceptability of Malaysian citizen towards living inside a house racking and interest of Malaysian citizen if a rack house is integrated thoroughly. Besides, this research would also provide an opportunity for government sector to revisit the issue of sustainability in the mass housing industry in particular and in the construction industry in general and also promote and create an alternative solution to affordable housing programmes for the mass housing industry in Malaysia [6].

\section{LITERATURE REVIEW}

\section{Definition and Characteristics of Rack House}

Rack housing is relatively new type of modular construction in Malaysia. Like other modular construction, it is generally manufactured in the factory and are delivered to the site as the main structural elements of the building. Such modular units may also be manufactured for higher value components of the building, such as bathrooms, lift and stair units, mechanical serviced units, prefabricated roofs, and often incorporating services [5,7,8].

Unlike other types of modular construction, rack housing is noted to be flexible to the demand of the potential user from the perspective of design and the structures [9-11]. Besides, it is an ideal type of house particularly for those with profesions that requires high mobility. Rack housing can also be reffered as an affordable house that generates higherquality production in the factory, improves productivity and performance, shortens project cycles, is scalable and costeffective (mass customization), and decreases workplace safety and health hazards [10]. In addition, rack housing construction has built ecological architecture and building technologies to reduce the impact on the environment [12-14]. 


\section{METHODOLOGY}

\section{Research Respondent}

According to [15], the sample size is calculated by the number of targeted respondents. The target respondents include any potential buyer of any age, race, household income, marital status, or other factors. Throughout the analysis, a random sampling technique was used. Each respondent in the population has an equal chance of being included in the survey using this method.

It is, however, impossible to obtain data from the entire population. As a consequence, the required sample size should be calculated. The sample size should be large enough to reflect or confirm the population's outcome. According to [16], a greater sample size is preferable because it reduces sampling errors. Saunders and Lewis [16] also proposed that the sample size needed for the analysis be determined using Equation (1) since the population is uncertain and can only be estimated.

$$
\boldsymbol{n}=\frac{Z^{2} P(1-P)}{e^{2}}=\frac{2.575^{2}(0.5)(1-0.5)}{0.09^{2}} \approx 205
$$

where $\mathrm{n}$ is the minimum sample size, $\mathrm{Z}$ is the statistical value for the confidence interval used $(2.575$ for confidence interval of $99 \%$ ), $\mathrm{P}$ is the population proportion which is being estimated (50\%) and e is the sampling error of the point estimate (9\%). Therefore, a minimum of 205 responded is required. In this research study, survey questionnaire is the most suitable method to be used to collect primary data that are relevant to residential property. Researcher used online survey questionnaire which generated in Google form.

\section{Question Design and Data Collection}

To study effectively, two types of primary data collections system were adopted. It focuses on the acceptance level of rack housing. All the primary data collected through questionnaires are strictly private and confidential. The survey questionnaire is a structured questionnaire which contain a set of relevant questions with choices of answers that the respondents would choose from. The primary data collected through questionnaire is divided into two sections. Each section is specifically designed to cater the different types of respondent, different types of research purpose and to answer different types of research question. Section A, independent variable, is designed for the demographic of respondents and Section B, dependent variable, is designed to test the acceptability of the public towards rack housing. In this research, the instruments used are survey questionnaire with variety types of question. This questionnaire created in the Google Docs, and invited to participate in this survey.

Respondents used the given Likert scale to show their degree of agreement or disagreement. The respondent had more flexibility to select the right option from a wider collection of options rather than a close-by option. In order to collect the respondent's opinion for this analysis, the Likert scale which ranges from 1-5 (as shown in Table 1) is used. The average index method has been adopted for analysis purpose.

Table 1. Example of Likert scale

\begin{tabular}{lccccc}
\hline & 1 & 2 & 3 & 4 & 5 \\
Factor & Strongly Disagree & Disagree & Neutral & Agree & Strongly Agree \\
\hline Property Attribute & & & & & \\
Flexibility of design & 0 & 0 & 0 & 0 & 0 \\
Finishing & 0 & 0 & 0 & 0 & 0 \\
\hline
\end{tabular}

\section{RESULT AND DISCUSSIONS}

The data collected from the questionaires are analysed and interpreted to meet the objectives of the study. The data are presented in clear and concise forms, name figures and tables. In total, the study has received 208 respondents with the age fall in the range of 19-69 years old.

\section{Data from Independent Variable}

Table 2 shows the survey respondents from different background from Malaysia. This questionnaire survey is conducted 208 respondents from the age of below 19 to 75 above years old. Researcher assumed that Malaysian citizen between the age of 18 to 30 years old are considered to be the future prospect rack housing buyer, for implementation of modular construction project. The respondents from different states are accepted as to represent the whole Malaysia citizen. 
Table 2. Respondent's Profile

\begin{tabular}{|c|c|c|}
\hline Demography & Frequency & $(\%)$ \\
\hline \multicolumn{3}{|l|}{ Gender } \\
\hline Female & 114 & 54.8 \\
\hline Male & 94 & 45.2 \\
\hline \multicolumn{3}{|l|}{ Age } \\
\hline$<19$ & 11 & 5.3 \\
\hline $20-24$ & 85 & 40.9 \\
\hline $25-29$ & 48 & 23.1 \\
\hline $30-34$ & 11 & 5.3 \\
\hline $35-39$ & 23 & 11.1 \\
\hline $40-44$ & 12 & 5.8 \\
\hline $45-49$ & 4 & 1.9 \\
\hline $50-54$ & 9 & 4.3 \\
\hline $55-59$ & 1 & 0.5 \\
\hline $60-64$ & 1 & 0.5 \\
\hline $65-69$ & 3 & 1.4 \\
\hline \multicolumn{3}{|l|}{ Marital Status } \\
\hline Divorced & 3 & 1.4 \\
\hline Married & 50 & 24.0 \\
\hline Single & 154 & 74.0 \\
\hline Widowed & 1 & 0.5 \\
\hline \multicolumn{3}{|l|}{ Monthly Income } \\
\hline$<$ RM3000 & 110 & 52.9 \\
\hline RM3000-RM4999 & 51 & 24.5 \\
\hline RM5000-RM6999 & 23 & 11.1 \\
\hline RM7000-RM9999 & 18 & 8.7 \\
\hline RM10000 and above & 6 & 2.9 \\
\hline \multicolumn{3}{|c|}{ Educational background } \\
\hline Primary & 5 & 2.4 \\
\hline Secondary & 51 & 24.5 \\
\hline Tertiary & 148 & 71.2 \\
\hline Master & 4 & 1.9 \\
\hline
\end{tabular}


Table 2. Respondent's Profile (cont.)

\begin{tabular}{lcc}
\hline Demography & Frequency & $(\%)$ \\
\hline Occupation & 18 & 8.7 \\
Clerical Support Workers & 6 & 2.9 \\
Craft and Related Trades Workers & 17 & 8.2 \\
Elementary Occupations & 15 & 7.2 \\
Managers & 4 & 1.9 \\
Plant and Machine Operators and Assemblers & 55 & 26.4 \\
Professional Service and Sales & 23 & 11.1 \\
Workers & 3 & 1.4 \\
Skilled Agricultural, Forestry and Fishery Workers & 24 & 11.5 \\
Technicians and Associate Professionals & 39 & 18.8 \\
Students & 4 & 1.9 \\
Others & & \\
\hline Home Ownership & 91 & 43.8 \\
Family Home & 57 & 27.4 \\
Own Home & 60 & 28.8 \\
Rented Home & & \\
\hline Workplace & 142 & 68.3 \\
Hometown & 66 & 31.7 \\
Outside Hometown & \multicolumn{3}{c}{} \\
\hline Work Location & 120 & 57.7 \\
Rural Area & 42.3 \\
\hline Urban Area & & \\
\hline & & \\
\end{tabular}

\section{Data from Dependent Variable}

For this study, the factors considering in acceptance level of rack housing in Malaysia are divided into 12 categories which are property attribute, structural attribute, comfortability, cost, construction, location, management, technicality, financial, economic incentives, construction laws and regulations and property investment. Moreover, Table 3 and Table 4 listed out the factors. According to the data analysis, there are some sub factors that contribute to the acceptance. For Table 3 shows the rank for sub factors of the respondents. It is clearly seen that majority of the respondents agreed to accept the concept of rack housing.

Table 3. Sub-factors towards the Acceptance Level of Rack House in Malaysia

\begin{tabular}{|c|c|c|c|}
\hline Factors & & Average Index & Rank \\
\hline \multicolumn{4}{|l|}{ Property Attribute } \\
\hline Flexibility of design & & 3.8365 & 1 \\
\hline Finishing & & 3.7163 & 2 \\
\hline Affordability & & 3.6587 & 3 \\
\hline Size & & 3.6538 & 4 \\
\hline \multicolumn{4}{|l|}{ Structural Attribute } \\
\hline Internal and External & Structural Design & 3.8990 & 1 \\
\hline Layout Plan & & 3.8365 & 2 \\
\hline Exterior Features & & 3.8125 & 3 \\
\hline
\end{tabular}


Table 3. Sub-factors towards the Acceptance Level of Rack House in Malaysia (cont.)

\begin{tabular}{|c|c|c|}
\hline Factors & Average Index & Rank \\
\hline Number of Bathrooms & 3.7548 & 4 \\
\hline Size of the Living Area or Dining Area & 3.6202 & 5 \\
\hline Number of Rooms & 3.5769 & 6 \\
\hline Home Security & 3.5673 & 7 \\
\hline \multicolumn{3}{|l|}{ Comfortability } \\
\hline Sewage Treatment System & 3.9567 & 1 \\
\hline Ventilation System & 3.9375 & 2 \\
\hline Water Supply System & 3.8894 & 3 \\
\hline Air Conditioning System & 3.8894 & 3 \\
\hline Lighting System & 3.8029 & 5 \\
\hline Noise Cancelling System & 3.7885 & 6 \\
\hline Heating System & 3.7019 & 7 \\
\hline \multicolumn{3}{|l|}{ Cost } \\
\hline High Transportation Cost & 3.5865 & 1 \\
\hline High Maintenance Cost & 3.7067 & 2 \\
\hline High Labor Cost & 3.6827 & 3 \\
\hline High Construction Cost & 3.3750 & 4 \\
\hline \multicolumn{3}{|l|}{ Construction } \\
\hline Completion Time & 3.9087 & 1 \\
\hline Site Materials & 3.8942 & 2 \\
\hline Construction Time on Site & 3.8654 & 3 \\
\hline Wastage on Site & 3.7115 & 4 \\
\hline Transportation Time & 3.5337 & 5 \\
\hline Production Time in Factory & 3.4423 & 6 \\
\hline \multicolumn{3}{|l|}{ Location } \\
\hline Crime Rate & 4.0385 & 1 \\
\hline Accessibility of Basic Infrastructure & 4.0192 & 2 \\
\hline Safety of the Neighborhood & 3.8942 & 3 \\
\hline \multicolumn{3}{|l|}{ Management } \\
\hline Efficiency in Delivery & 3.9231 & 1 \\
\hline Experienced Workforce & 3.9183 & 2 \\
\hline Experienced Supervision and Control & 3.8798 & 3 \\
\hline Scheduling in Construction & 3.6971 & 4 \\
\hline Advanced Machinery & 3.6635 & 5 \\
\hline \multicolumn{3}{|l|}{ Technicality } \\
\hline Specification Meets Standard Requirements & 3.8750 & 1 \\
\hline Adequate Site Investigation & 3.8654 & 2 \\
\hline Plenty of Resources Availability & 3.7067 & 3 \\
\hline
\end{tabular}


Table 3. Sub-factors towards the Acceptance Level of Rack House in Malaysia (cont.)

\begin{tabular}{|c|c|c|}
\hline Factors & Average Index & Rank \\
\hline \multicolumn{3}{|l|}{ Financial } \\
\hline High Capital Cost & 3.7740 & 1 \\
\hline Leasing Equipment and Manpower Cost & 3.7596 & 2 \\
\hline Fluctuation and Increase of Material Cost & 3.5625 & 3 \\
\hline Low Return Investment & 3.4279 & 4 \\
\hline \multicolumn{3}{|l|}{ Economic Incentives } \\
\hline Award & 3.6875 & 1 \\
\hline Tax Break on Capital & 3.6875 & 1 \\
\hline Subsidy & 3.5144 & 3 \\
\hline \multicolumn{3}{|l|}{ Construction Laws and Regulations } \\
\hline Standardization of Project Design & 3.8702 & 1 \\
\hline Promote Mechanization and Construction & 3.8365 & 2 \\
\hline $\begin{array}{l}\text { Ease of Application for Construction Permit or } \\
\text { Temporary Construction }\end{array}$ & 3.8269 & 3 \\
\hline $\begin{array}{l}\text { Performance of Modular Building Meets Mandatory } \\
\text { Requirements }\end{array}$ & 3.6731 & 4 \\
\hline $\begin{array}{l}\text { Administrative Procedures of Prefabricated } \\
\text { Components }\end{array}$ & 3.5865 & 5 \\
\hline
\end{tabular}

Table 4 shows the ranking of the main factors related to racking house. Among the 11 factors, location ranked in the first place with the average index value of 3.9840. It is followed by comfortability and management which ranked second and third with the average index value of 3.8523 and 3.8164 respectively. Eren [17] further suggested that good management could improve the quality of production resulting in higher confidence level among the investors.

In contrast, the lack of proper modular construction codes and standards is a significant barrier for contractor to widespread adoption of modular construction, considering the recent development of some modular architectural guidelines [18-20]. Due to lack of professional and experienced designers also the facts that modular construction cannot be widely used [8,21]. The construction laws and regulations ranked fifth with the average index of 3.7586. Kamar [9] stated that government agencies of Malaysia have a lack of governmental roles and programmes for implement modular construction. But for the past few years there is improvement of policy framework for smart development and green technologies to monitor and implement the country's sustainability agenda. It can be clearly seen that modular construction made progress in Malaysia with the creation of green technology guidelines and qualifications [8]. The construction, structural attribute, property attribute, financial, economic incentives and cost the bottom six important.

From Table 4 it is observed that most of the respondents agreed to accept the concept of rack housing. However, the main factors for the rack house acceptance flows in the following sequence namely, location, comfortability, management, technicality, construction laws and regulations. The construction factors, structural attribute, property attribute, financial, economic incentives and cost respectively ranked the in the bottom as least important.

Navaratnam, et al. [22] who concluded that the knowledge of modular construction needs proper communication and enhancement in order to allow for better implementation where able to increase the acceptance level even more. Because lack of knowledge about modular construction leads to various complications for all participants, some of them fail to do their part effectively due to this problem while others provide poor quality outputs for the same reason [23,24]. The problem gets even more inflated when owners are not aware of what $\mathrm{MiC}$ is and how it works so they tend to avoid it or sometimes neglect its benefits $[25,26]$. 
Table 4. Rank According to Main Factor

\begin{tabular}{lcc}
\hline Factors & Average Index & Rank \\
\hline Location & 3.9840 & 1 \\
Comfortability & 3.8523 & 2 \\
Management & 3.8164 & 3 \\
Technicality & 3.8157 & 4 \\
Construction Laws and Regulations & 3.7586 & 5 \\
Construction & 3.7260 & 6 \\
Structural Attribute & 3.7239 & 7 \\
Property Attribute & 3.7009 & 8 \\
Financial & 3.6310 & 9 \\
Economic Incentives & 3.6298 & 10 \\
Cost & 3.5877 & 11 \\
\hline
\end{tabular}

\section{CONCLUSION}

From the finding, the concept of racking house is accepted by the Malaysian with the top five factors according to sequence are location, confortability, management, technicality, construction laws and regulations. The introduction of rack housing implies a radical change in the housing market. However, the housing industry which is perceived as incapable of providing decent housing to the to the urban community should uplift their credibility by producing high quality and affordable housing scheme.

It is concluded that Malaysians are ready to adopt the concept of racking house that promotes new perspective of construction building method which is mobile and flexible. However, a prototype and a workable analysis of the individual unit also should further developed (single unit with utilities and services). The prototype would foster cooperation among the housing industry and the marketing campaign for young Malaysians on alternative housing choices. As recommendation, future research can investigate the perception of expertise in construction industry and government sector about the feasible development of rack house in Malaysia.

\section{REFERENCES}

[1] Economic Planning Unit E, "Eleventh Malaysia Plan, 2016-2020: Anchoring growth on people," in Rancangan Malaysia Kesebelas (Eleventh Malaysia Plan): 2016-2020, 2020, pp. 1-372.

[2] F. C. Chia, U. Tunku, A. Rahman, and M. Skitmore, "An analysis of construction productivity in Malaysia," Constr. Manag. Econ., vol. 30, no. 12, pp. 1055-1069, 2012, doi: 10.1080/01446193.2012.711910.

[3] Cagamas Holdings Berhad, Housing the nation: policies, issues and prospects. 2013.

[4] Modular Building Institute, “2020 Permanent Modular Construction Report,” 2020.

[5] S. Aziz and M. R. Abdullah, "Modular Construction System in Malaysia: Issues for Research in Sustaining an Affordable Home Project," Proc. Postgrad. Conf. Glob. Green Issues (Go Green), vol. 2020, no. October 2015, 2015.

[6] M. Z. Bin Mohd Noor, "FlexZhouse: New business model for affordable housing in Malaysia," A+BE Architecture and the Built Environment, vol. 2. 2017.

[7] M. Lawson, R. Ogden, and C. Goodier, Mark Lawson Design in Modular Construction. 2014.

[8] K. A. M. Kamar, M. N. A. Azman, and M. N. M. Nawi, "IBS survey 2010: Drivers, barriers and critical success factors in adopting industrialised building system (IBS) construction by G7 contractors in Malaysia," J. Eng. Sci. Technol., vol. 9, no. 5, pp. 490-501, 2014.

[9] L. Eric and K. Kamar, "Industrialised Building Systems ( IBS ) - A Strategic Outlook of Manufactured Construction in Malaysia,” J. Archit. Eng., vol. 18, no. 2, pp. 69-74, 2012.

[10] M. F. Musa, M. R. Yusof, M. Fadhil, and R. Mahbub, "Characteristics of Modular Construction: Meeting the Needs of Sustainability and Innovation," IEEE Colloq. Humanit. Sci. Eng. Res., no. April, p. 6, 2014.

[11] B. R. Sinclair, S. Mousazadeh, and G. Safarzadeh, "Agility, Adaptability + Appropriateness: Conceiving, Crafting \& Constructing an Architecture of the 21st Century," Enq. ARCC J. Archit. Res., vol. 9, no. 1, 2012.

[12] R. M. Lawson and R. G. Ogden, "Sustainability and Process Benefits of Modular Construction," 18th CIB World Build. Congr., pp. 38-51, 2010 .

[13] Modular Building Institute, "Permanent Modular Construction 2013 Annual Report," 2013.

[14] Modular Building Institute, "Improving Construction Efficiency and Productivity with Modular Construction,” 2010. 
[15] J. Furuse and M. Katano, "Structuring of Sekisui Heim automated parts pickup system (HAPPS) to process indivisual floor plans,” 2006 Proc. 23rd Int. Symp. Robot. Autom. Constr. ISARC 2006, pp. 352-356, 2006, doi: 10.22260/isarc2006/0068.

[16] M. N. K. Saunders and P. Lewis, "Great ideas and blind alleys? A review of the literature on starting research," Manag. Learn., vol. 28, no. 3, pp. 283-299, 1997, doi: 10.1177/1350507697283002.

[17] H. Eren, A. R. I. F. Sirinterlikci, A. K. Akgul, and O. K. S. A. N. Imamoglu, Automation and Robotics in Processes. 2011.

[18] J. Murray-Parkes and Y. Bai, Handbook for the Design of Modular Structures. 2017.

[19] Z. Xu, T. Zayed, and Y. Niu, "Comparative analysis of modular construction practices in mainland China, Hong Kong and Singapore,” J. Clean. Prod., vol. 245, p. 118861, 2020, doi: 10.1016/j.jclepro.2019.118861.

[20] J. Zhu, P. Wu, M. Chen, M. J. Kim, X. Wang, and T. Fang, “Automatically processing IFC clipping representation for BIM and GIS integration at the process level," Appl. Sci., vol. 10, no. 6, 2020, doi: 10.3390/app10062009.

[21] N. Blismas and R. Wakefield, "Drivers, constraints and the future of offsite manufacture in Australia," Constr. Innov., vol. 9, no. 1, 2009, doi: 10.1108/14714170910931552.

[22] S. Navaratnam, T. Ngo, T. Gunawardena, and D. Henderson, "Performance review of prefabricated building systems and future research in Australia," Buildings, vol. 9, no. 2. p. 38, 2019, doi: 10.3390/buildings9020038.

[23] I. laili Jabar, F. Ismail, and A. A. Mustafa, "Issues in Managing Construction Phase of IBS Projects," Procedia - Soc. Behav. Sci., vol. 101, pp. 81-89, 2013, doi: 10.1016/j.sbspro.2013.07.181.

[24] H. Abdul Rahman and M. Hanid, "A Literature Review Of The Advantages And Barriers To The Implementation Of Industrialised Building System (IBS) In Construction Industry.," Malaysian Constr. Res. J., vol. 4, no. 1, 2009.

[25] M. Kamali and K. Hewage, "Life cycle performance of modular buildings: A critical review," Renewable and Sustainable Energy Reviews, vol. 62. pp. 1171-1183, 2016, doi: 10.1016/j.rser.2016.05.031.

[26] B. G. Hwang, M. Shan, and K. Y. Looi, "Key constraints and mitigation strategies for prefabricated prefinished volumetric construction," J. Clean. Prod., vol. 183, pp. 183-193, 2018, doi: 10.1016/j.jclepro.2018.02.136. 